INTERDISCIPLINARIA ARCHAEOLOGICA NATURAL SCIENCES IN ARCHAEOLOGY

\title{
Review of Illuvial Bands Origin; What Might the Presence of Dark Brown Bands in Sandy Infillings of Archaeological Features or Cultural Layers Mean?
}

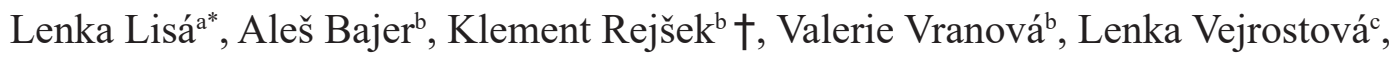 \\ Andrzej Wisniewski ${ }^{\mathrm{d}}$, Petr Krištuf ${ }^{\mathrm{e}}$ \\ anstitute of Geology CAS, Rozvojova 269, 16500 Prague, Czech Republic \\ ${ }^{b}$ Department of Geology and Pedology, Faculty of Forestry and Wood technology, Mendel University in Brno, Zemědělská 3, 613 00 Brno, Czech Republic \\ ${ }^{c}$ Faculty of Science, Charles University, Albertov 6, 12843 Prague, Czech Republic \\ ${ }^{d}$ Institute of Archaeology, University of Wrocław, Szewska 48, 50137 Wrockaw, Poland \\ ${ }^{e}$ Department of Archaeology, University of West Bohemia, Sedláčkova 15, 30614 Pilsen, Czech Republic
}

\section{A RTICLE INFO}

\section{Article history:}

Received: $27^{\text {th }}$ June 2018

Accepted: $1^{\text {st }}$ May 2019

DOI: http://dx.doi.org/ 10.24916/iansa.2019.1.2

Key words:

illuvial bands

clay-iron accumulations

subsoil lamellae

micromorphology

Neolithic

Palaeolithic

\begin{abstract}
$A B S T R A C T$
The presence of lamellae (or bands) often promises an interesting sedimentary archive related to the occupation or abandonment history of a site. How exactly might such types of bands be interpreted, and how do their presence change the original primary features preserved within the archaeological structure? For this review, two archaeological sites are introduced, both distinct in many aspects, located in different climatic regions, but with the presence of bands preserved inside of the infill, as well as in the locality's background. One site is related to the Magdalenian/Epigravettian occupation in south-western Poland, and the second related to the Neolithic occupation in central Bohemia. What connect these two localities are their permeable sandy background, presence of human occupation, and the development of the above-described textural features. Sedimentological observations supported by micromorphology and geochemistry, as well as by magnetic susceptibility, revealed that, in both localities, the presence of dark brown bands was the result of repeated illuviation due to a kind of podsolization process not necessarily related to human presence. The illuvial lamellae/bands at the Kly site probably originated during the Subboreal due to the increased humidity connected with the presence of the disturbed background of the infill in the ditch. The Sowin site displays, at the very least, two phases of origin. One of the phases is pre-dated by glacial conditions, and the second is of late glacial or Holocene origin. The origin of these features in both study sites is due to precipitated water and the movement of clay down the section, but under their different conditions.
\end{abstract}

\section{Introduction}

The presence of bands within the sedimentary/pedological record has been of interest to different pedologists since the beginning of the twentieth century. The most common term for these laminated textural features are illuvial bands, but names such as pseudofibres, lamellas, laminae, clay-iron bands or covarvany, are also used in different references (see review, Prusinkiewicz et al., 1998 and Kühn et al., 2011), or, according to the US Soil Survey Staff (1999), a lamella. A textural feature called a lamella (plural lamellae; band) can develop as an illuvial horizon with a thickness

*Corresponding author. E-mail: lisa@gli.cas.cz of less than $7.5 \mathrm{~cm}$ and is intercalated with horizons poor in clay (Miedema, 1987; Kemp and McIntosh, 1989). Such accumulations are usually composed of fine-grained, silicarich clay attached to a coarser fraction that is composed of the original soil. Illuvial bands differ in colour (higher chroma values, redder hues) (Van Reeuwijk and de Villiers, 1985). The transition between bands and the surrounding matrix is usually wavy and broken. Sometimes these bands compose a kind of web or network. A concave gefuric c/f-related (coarse/fine-related) distribution is the typical micromorphological pattern. Clay coatings cover and bridge the individual sand grains which is reflected in a chitonic or chito-gefuric c/f-related distribution (Kühn et al., 2011). Most commonly these bands are described in sandy soils, 


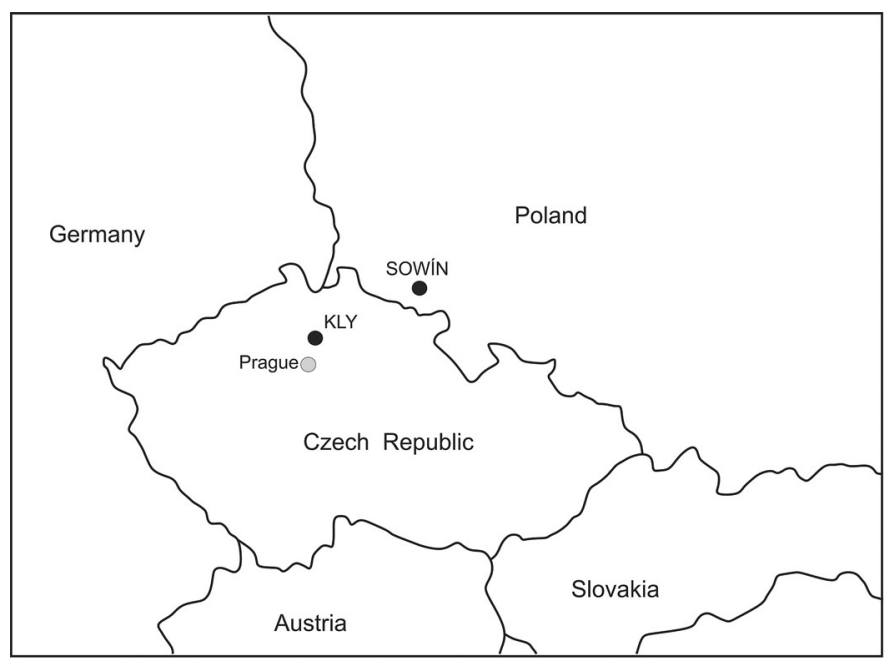

Figure 1. Lidar-based DTM data expression on both sites (A - Kly, B - Sowin) together with their location in central Europe.

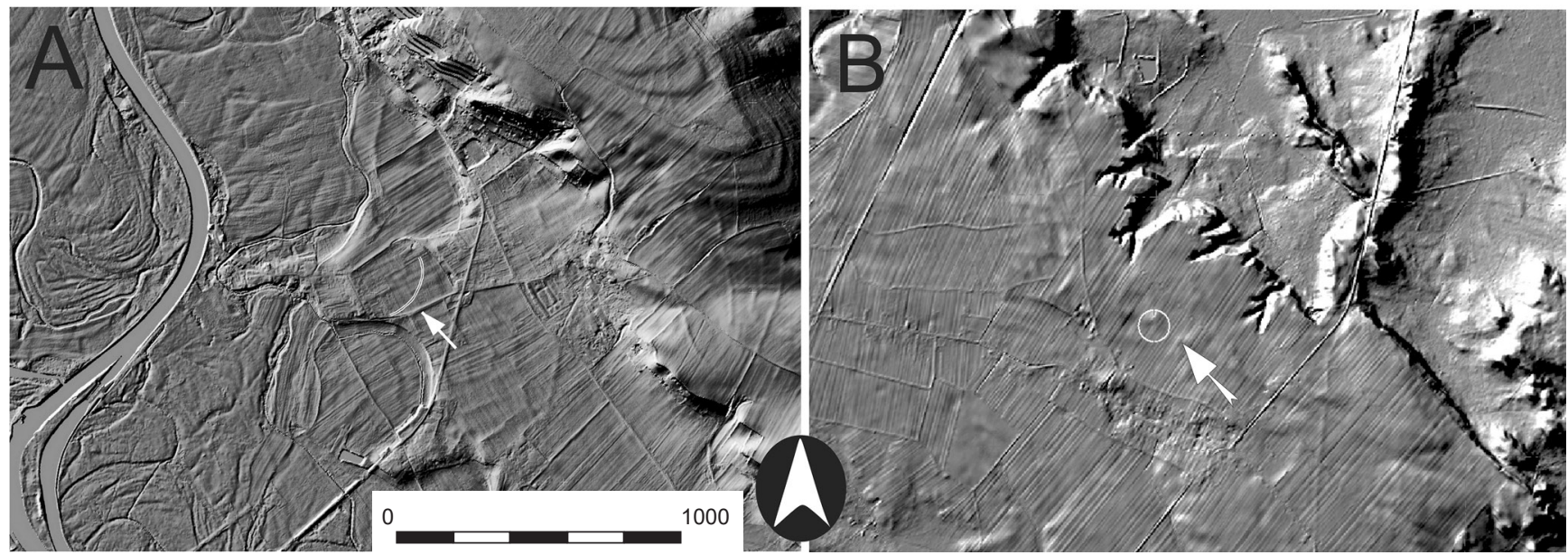

but their appearance in other soils is not excluded. Several of the best-developed examples of soils with illuvial bands described in Holocene (as well as Pleistocene) soils are the humic podzols of the European Aeolian Sand Belt (Koster, 2009). Gerasimova and Khitrov (2012) classified similar soils located in glacifluvial sand in south western Poland.

What is the process whereby the illuvial bands develop? What role does climate, natural processes, or human influence play in the origin of these features? The origin of illuvial bands is generally not well understood and it remains controversial. It seems that some "trigger" (increased precipitation - Pelle et al., 2013) activates the movement of clay, which then stops moving at a certain depth where there is some textural inhomogeneity (Bouabid et al., 1992). Another possibility is that the origin is triggered by the precipitation, but these bands start to form at the limit of the capillary water reach (Van Reeuwijk and de Villiers, 1985), or on a transition to a more calcareous zone, i.e. at a point of a distinct $\mathrm{pH}$ change (Schaetzl, 1992). Stefanovits (1971) suggested that illuvial bands are the result of unfavourable conditions triggered by climate. On the other hand, the same author, as well as Tsigirintsev (1968) and Ugla and Ugla (1979), propose that illuvial bands are the result of the impact of forest vegetation. Their assumption is that the clay movement is activated by a change of $\mathrm{pH}$ that has been triggered by the acid "waste" from conifer trees. In this scenario, active maintenance of the vegetation by humans may play a role in the origin or absence of these features. Another trigger, differing from those mentioned above, is the local hydrology (see review in Ibrahim, 2011). Here the underground water is transporting a quantity of some iron compound that may transform at one point in time (and place) and thus form the illuvial bands. The primary sedimentary accumulation of iron, and later pedological transformation of these accumulations, may also play a role in the development of these bands (Schaetzl, 2001).

This paper aims to review the possible formation processes that lead to the origin of illuvial bands and, in addition, how micromorphology and geochemistry methodological tools may help with interpreting these formation processes. What might the main triggers be and what exactly might the presence of illuvial bands mean for interpretation of human presence and the environment of a site?

\section{Study sites}

\subsection{Kly}

The Kly site is situated at the confluence of the Labe and Vltava Rivers in central Bohemia (Figure 1A). The 
background of the site is composed of Cretaceous sand of Turonian Age covered by the fluvial sandy deposits of the Labe River. A Neolithic enclosure has been recorded there by way of an aerial survey. The enclosure is composed of two ditches and a stockade groove on the inside. The enclosure defines the area of a defunct bend in the River Labe and exceeds its alluvium (flood plain) by approximately 5 metres. The outside ditch was interrupted at 10 places and the inside at 13 places (Gojda et al., 2002). All three lines of the enclosure were partially excavated by trenches for the first time in 1999, and then again in 2015 (Krištůf et al., 2019).

The outer V-shaped ditch is 3.5-4.3 m wide at its top with a maximum depth of $1.4 \mathrm{~m}$. The inner ditch has a similar shape. Its width ranges from 3.7 to $4.1 \mathrm{~m}$ with a maximum depth of $1.3 \mathrm{~m}$. The ditches were dug into the sandy subsoil, resulting in the low stability of their walls. Shortly after the digging of these ditches, their bottoms were clogged up by sandy layers. The depth at that moment reached $0.9 \mathrm{~m}$ and $0.95 \mathrm{~m}$, respectively, and the ditches had a U-shape profile. Most of the findings associated with the enclosure were found in the layers above this horizon. The most frequent findings were large accumulations of daub and fragments of vessels. The authors managed to reconstruct two tulip-like beakers and pots. The upper part of the ditches was definitely filled up during agricultural cultivation in the Middle Ages or even the post-medieval Period. In both ditches, besides the above-described layers, there were also weak dark-brown layers that occurred at a depth of $0.7-1.3 \mathrm{~m}$ and went into the sandy subsoil. The same situation was observed during the research work in 1999, when these layers were the only stratification that had been recognized in the ditch's profile (Gojda et al., 2002).

The cause-way enclosure near Kly is classified to an early phase of the Michelsberg culture on the basis of the archaeological findings. This is evidenced mainly by findings of Tulip-like beakers of type II (according to Lüning, 1968). At least one beaker was found in both ditches. The same beaker type was found during the research work in 1999 (Gojda et al., 2002). Three radiocarbon dates have been retrieved from this site. Two of them came from the outside and the other came from the inner ditch. All three dated samples came from contexts with numerous archaeological findings. Both dates from the outer ditch are identical, $5195 \pm 40{ }^{14} \mathrm{C}$ BP. The date from the inner ditch is slightly earlier, $5230 \pm 30{ }^{14} \mathrm{C}$ BP. Formal similarities, archaeological findings and radiocarbon dates indicate the simultaneity of both ditches (Krištůf et al., 2019).

\subsection{Sowin}

The Sowin site is situated within the central part of the Niemodlin Plain, which separates the Nysa Kłodzka Valley from the Ścinawa Niemodlińska Valley, SW Poland (Figure 1B). The Niemodlin Plain rises ca. 40 metres above the bottom of the Nysa Kłodzka Valley and ca. 25 metres above the Ścinawa Niemodlińska Valley (Przybylski and Badura, 2001). The background of the study site is composed of relics of a till plain and glacifluvial sediments of the Odra glaciations (OIS6), partly covered by loess deposits (OIS2) and sand dunes (Dryas I-III as well as OIS2) with traces of Upper Palaeolithic settlement. The Late Palaeolithic record from the Sowin area comprises a number of sites (Wiśniewski et al., 2009; 2012). Three of them (nos. 7, 9 and 11) have yielded large collections (more than one thousand stone artefacts). The illuvial bands are a common feature in all the types of sandy sediments.

In this paper, we will only focus on site 7, which has been widely recognized. Sowin site 7 has provided data on human activity corresponding to the Epigravettian and Magdalenian. The Epigravettian finds occurred in sandy sediment overlying sand and gravel of glacial origin. Using OSL dating, the sediment in which the Epigravettian assemblage was located had formed in 15,470 $\pm 860{ }^{14} \mathrm{C} \mathrm{BP}$ (GdTL2496)

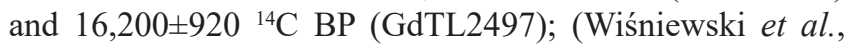
2017). The artefacts were buried by aeolian sand (up to $0.4 \mathrm{~m}$ thick). The sandy layer contains a network of fine desiccation cracks and isolated ice-wedge pseudomorphs as a result of periglacial processes. The aeolian sand was OSL dated between $13,830 \pm 860$ (GdTL2495) to $14,710 \pm 900 \mathrm{BP}$ (GdTL2494). The modern topsoil situated above was $0.3 \mathrm{~m}$ thick. The Magdalenian finds were recorded in the upper part of the aeolian sand and in the topsoil. Artefacts below the ploughing zone had survived in local depressions that were probably of thaw origin, inherited from the periglacial period. Spatial analysis and a technological study of this assemblage allowed us to distinguish two different functional clusters connected with blank (stone tool) production and the production and use of tools such as burins, endscrapers, and backed pieces. Ochre was also confirmed in the layer. The second artefact cluster was situated in the context of fillings of the periglacial structures such as ice wedges or desiccation cracks.

\section{Methods}

Both sites included in this study were evaluated during archaeological excavations. The presence of illuvial bands outside the archaeological context was, in the case of the Sowin site, recorded by a set of cores as well as trenches, and these bands were also recorded in the straight context of the cultural layer. To better understand the illuvial band formation, trench 7/IV was chosen for the geochemical evaluation, in spite of the fact that it was archaeologically sterile. On the other hand, trench 7/IV provided a lithology where sand covered by loess was preserved. Micromorphological samples documenting the bands lithology were taken from trench 7/IV as well as from the other trenches where only sandy material and human occupation was documented (7/I, 7/II). Concerning the stratigraphy of the site, it is suggested that the formation of trench 7/IV preceded the Epigravettian and Magdalenian occupation of the area (Wisniewski et al., 2017).

In the case of the ditch infill in Kly, illuvial bands were recorded mainly inside the ditch, but partly also in its 

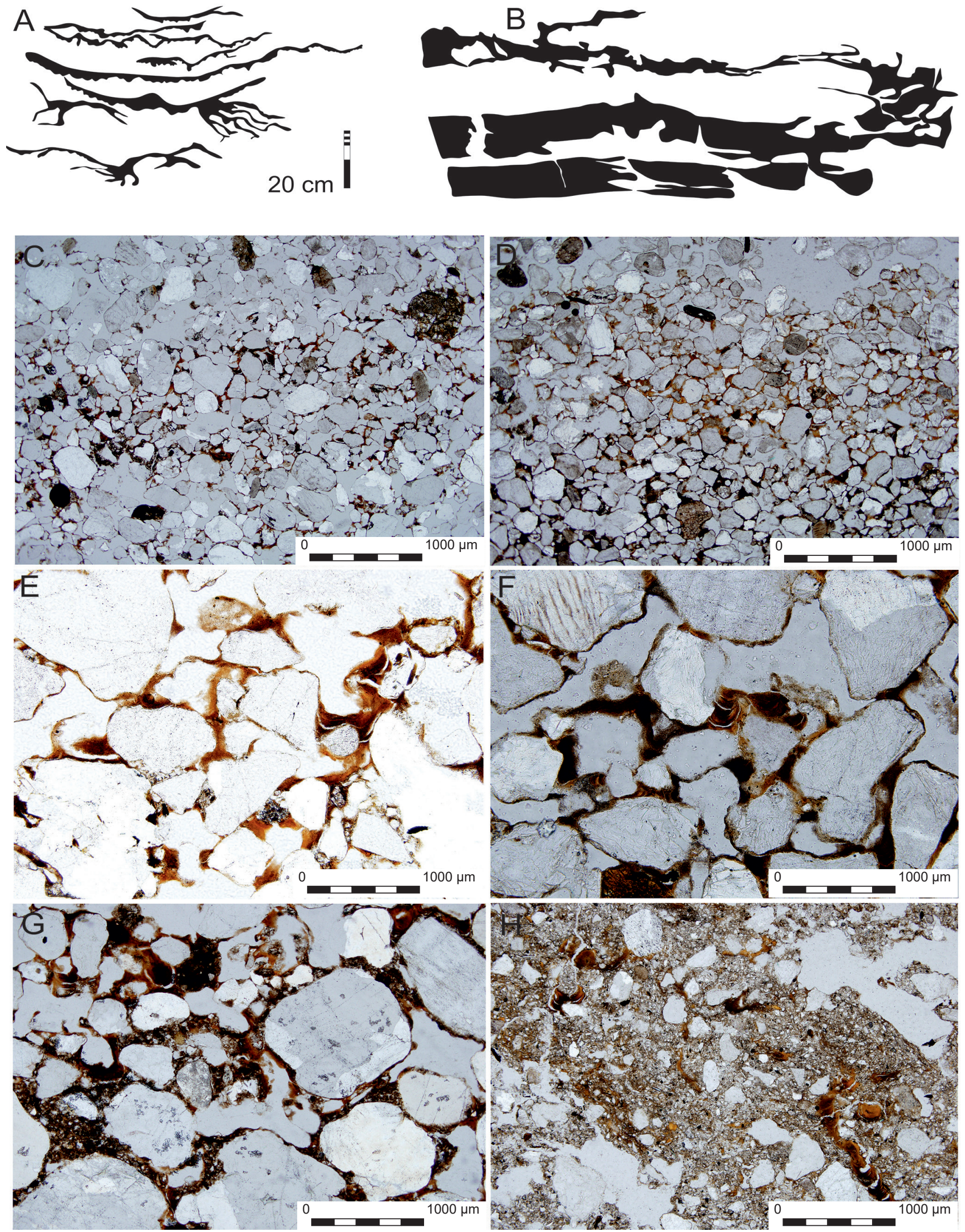

Figure 2. Drawings of the thickness and shape of the illuvial bands recorded in the studied sites (A - Kly, B - Sowin); photodocumentation of the micromorphological features (C, E, G for the Kly site and D, F, H for the Sowin site). Both sites display the common presence of a dark coloured multilayered coating, which is usually connected with the presence of an illuviated silt fraction that has accumulated below or within the clay coating (clearly visible in $\mathrm{G}$ and $\mathrm{H}$ ). 

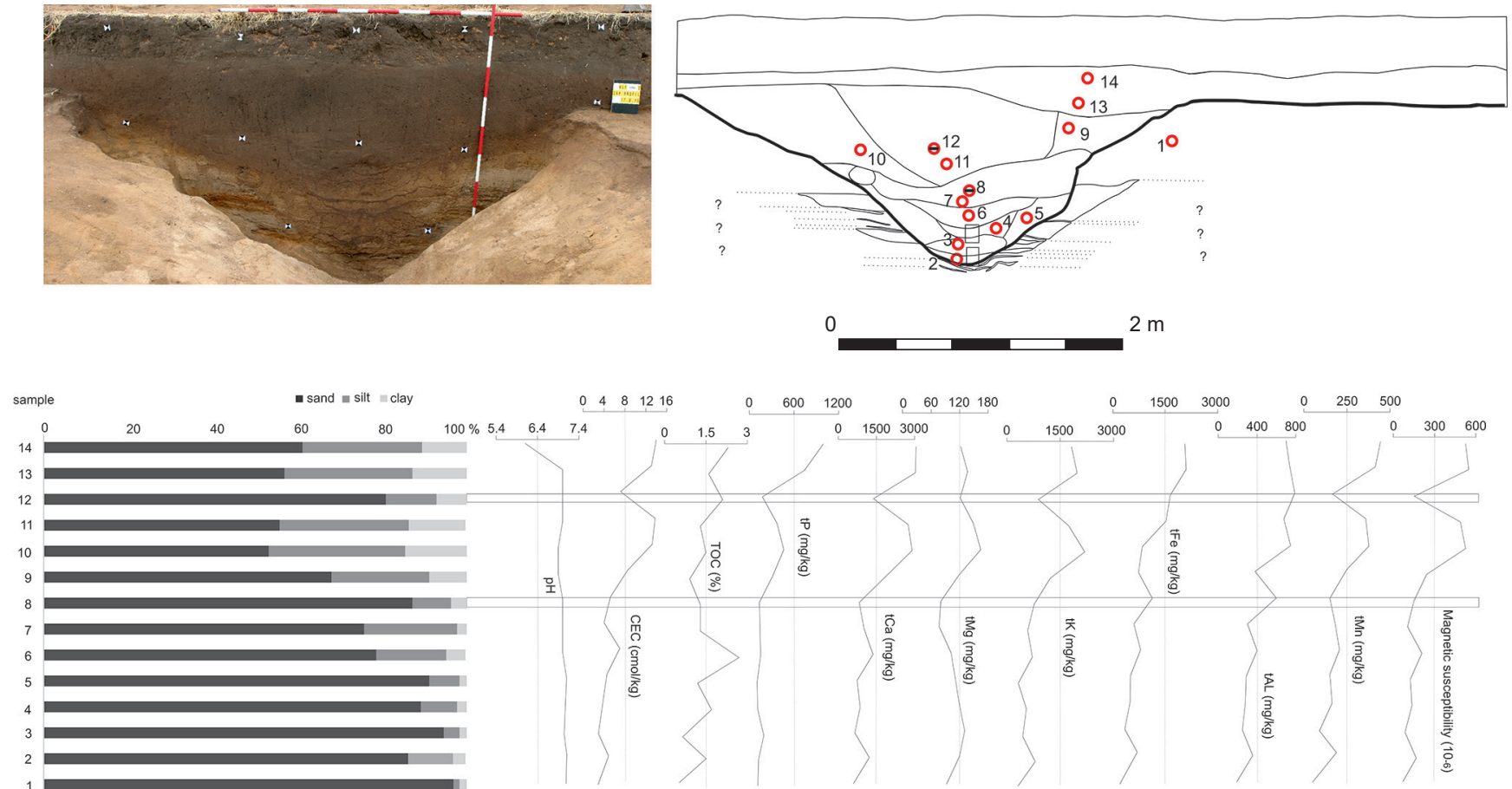

Figure 3. Photodocumentation of the infill of the Neolithic ditch from Kly, together with the sampling position and proxy record (grain size analyses, pH, CEC, TOC, P, Ca, Mg, K, Fe, Al, Mn and magnetic susceptibility).

surroundings though to a lesser extent. After the standard sedimentological description and geomorphological evaluation of the study site, micromorphological samples were taken from different lithological layers (Figure 3) as well as a number of bulk samples documenting the main lithological units. The micromorphological samples were dried and impregnated by Pollylite 2000 resin in vacuum. After curing, the thin sections were performed and studied under binocular $(1 \times-32 \times$ magnification $)$ and polarizing $(16 \times-800 \times$ magnification) microscopes. Bulk samples were subjected to the analyses of Mehlich III, for CEC (cation exchange capacity), $\mathrm{pH}$, TOC (total organic carbon), magnetic susceptibility and grain size distribution. The number of geochemical samples and the sampling interval depended on the lithology, which differs between sites (Figures 3 and 4).
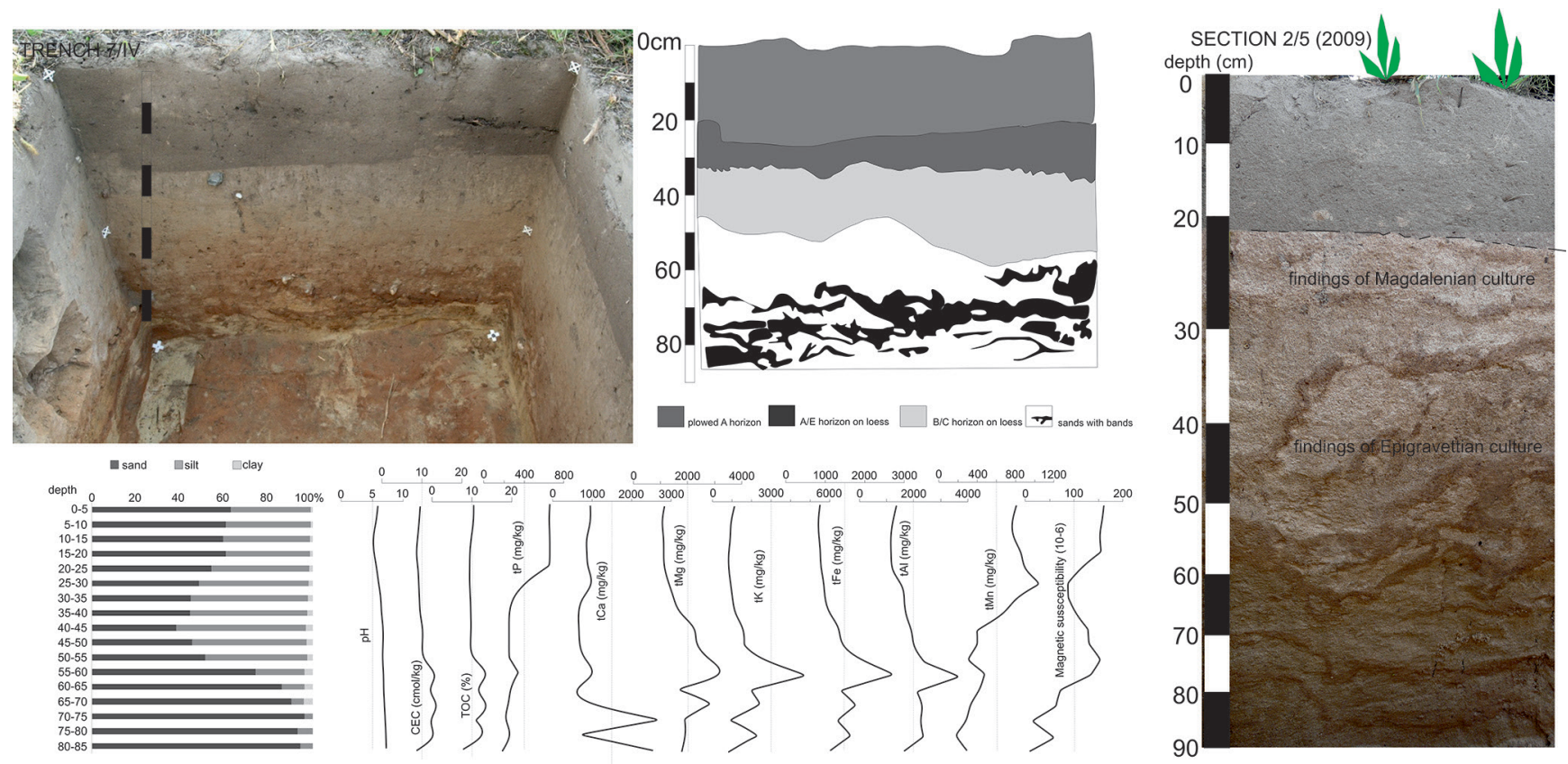

Figure 4. Photodocumentation of the trench 7/IV and section $2 / 5$ from the Sowin site with the proxy record (grain size analyses, $\mathrm{pH}, \mathrm{CEC}, \mathrm{TOC}, \mathrm{P}, \mathrm{Ca}, \mathrm{Mg}$, $\mathrm{K}, \mathrm{Fe}, \mathrm{Al}, \mathrm{Mn}$ and magnetic susceptibility) for the trench 7/IV. 
Chemical analyses included ICP EOS analyses on an Intrepid DUO spectrometer (ThermoFisher) of the main macroelements detected from two different solutions. The first, identified as $\mathrm{HCl}$ leachate (intended for a total dissolution of carbonate and a dissolution of unstable silicates, leaving quartz grains and stable silicates intact), was prepared by the reaction of a sample with $20 \%$ aqueous hydrochloric acid, and the second, reflecting the plant available elements, was detected by Mehlich III extraction (Sparks, 1996). Total carbon (TC) concentrations (\%) were measured on dry sediment ( $\sim .5 \mathrm{~g})$ using a PRISMACS analyser. The organic carbon was removed by firing at $500^{\circ} \mathrm{C}$ for 24 hours and the inorganic carbon content was measured by Leco analyser. The total organic carbon (TOC) content (weight percent) was determined from the difference between the total carbon and total inorganic carbon concentrations. The soil samples were tested for current soil acidity $\left(\mathrm{pH} / \mathrm{H}_{2} \mathrm{O}\right)$ and potential soil acidity $(\mathrm{pH} / \mathrm{KCl})$ using the potentiometric method with a glass electrode (soil: $\mathrm{H}_{2} \mathrm{O}$ or $1 \mathrm{M} \mathrm{KCl}=1: 2.5$ ) (Grant et al., 1996).

Magnetic susceptibility was measured using an Agico MFK1-FA Kappabridge at one operating frequency, $\mathrm{f} 1=976 \mathrm{~Hz}$, and the amplitude of the AC field was $200 \mathrm{~A} / \mathrm{m}$ (peak value). For the measurement, the bulk samples with known weight were used. Finally, the mass susceptibility was recounted. Grain size distribution was measured using a laser granulometer CILAS 1190 LD providing a range from 0.04 to $2,500 \mu \mathrm{m}$. The data were obtained after dispersion in $\mathrm{KOH}$, removing carbonates and organic matter. The data are reported in three fractions: clay (up to 2 micrometres), silt (2-63 micrometres) and sand (63-2,000 micrometres).

\section{Results and interpretations}

\subsection{Kly}

Thin illuvial bands were, in the case of the Kly section, recorded macroscopically mainly in the lower part of the ditch infill. These bands were approximately a few $\mathrm{mm}$ to a few $\mathrm{cm}$ thick (Figure 2a), and composed of clayey silt and sand (Figure 2c, 2e, 2g) with brown to orange brown colour. These thin bands are not hard and have more or less a horizontal orientation. Their shape remains a kind of a web (Figure 2a). The thickness variation seems not to be dependent on the grain size distribution of the infill, but it seems that an increase of the silty fraction is commonly linked to these accumulations. This trend is not well visible from the grain size distribution but was observed from thin sections. The top of the bands is straight and smooth whereas the bottom is uneven. Their appearance was not limited by the changing colour hue or grain size distribution of the sedimentary horizons through which these bands developed (Figure 3). In a closer view, bands were also recorded in the upper part of the infilling within a dark-brown, homogenous type of infill. The number of these bands was probably even higher than recognized, but the dark colour of the infill restricted their identification. The presence of thin bands is not strictly limited to the infill of the ditch and was also observed in smaller amounts outside the ditch.

Micromorphological samples taken through the bands retrieved the presence of clay accumulations that were not necessarily continuous, but more or less distributed in patches. It was observed that, macroscopically, the clay-like layer was in fact composed of a silty matrix with an abundance of sand grains and occasional clay accumulations. This fact corresponds to the measured grain size distribution, which did not stand out from the horizons above or below. It seems, according to the shape of the clay accumulations (Figure 2c, $2 \mathrm{e}$, and $2 \mathrm{~g}$ ), that they originated due to the distribution of the clay minerals from the upper horizons to the lower horizons. The geochemical record retrieved from the thin bands showed mainly an increase of $\mathrm{Al}, \mathrm{Fe}$ and $\mathrm{TOC}$, whereas the other proxies such as $\mathrm{CEC}, \mathrm{Ca}, \mathrm{K}, \mathrm{Mn}$ and magnetic susceptibility showed lower values (Figure 3 ). Some of the proxies showed none or very slight changes within the horizons with and without bands $(\mathrm{pH}, \mathrm{P}, \mathrm{Mg})$. There is a visible decrease of $\mathrm{pH}$ in the uppermost horizon, an enhancement of magnetic susceptibility and a mainly increasing trend of $\mathrm{P}, \mathrm{Mn}, \mathrm{Fe}$ and CEC towards the soil surface. The lower part of the infill shows a higher lithologic variability in the macroscopic observations and grain size distribution, but less variability in the values of the geochemical proxies (except for TOC), which corresponds to the changes in magnetic susceptibility.

The presence of archaeological findings or micromorphological features connected with human activity in the studied deposits was quite limited and activity was not dependent on the presence or absence of the studied illuvial bands. Rather contrary to this, the origin of the bands was post depositional, smoothed, and made the differences between different horizons of the infill more difficult to recognize.

\subsection{Sowin}

The presence of the bands was detected by the drilling equipment at different depths (up to $100 \mathrm{~cm}$ ) over the large area of the Sowin plain (Figure 1B) and also commonly recorded in excavated areas. The thickness of the bands differed from a few millimetres in the upper part of the sections (Figure 4, section 5/1) up to a few centimetres likely in the lower part of the sections (Figure 2B; Figure 4, trench 7/IV). Compared with the Kly site there appeared to be bands of different types, and not connected stratigraphically with human occupation in every case. Those located in the deeper horizons were more compact and thicker. Some of them were interrupted by frost features, i.e. they had already originated during the glacial period. The colour of these bands was usually a brownish orange and their lower as well as upper surface was usually smooth (Figure 2B). The excavated sections, which displayed a sandier infill not covered by loess (for example, section 5/1, Figure 4) also provided a type of illuvial bands more similar to the Sowin structures, i.e., with the orange colour and a more wavy, web-like shape. The thickness variation seemed not to be dependent on the primary grain size distribution, but in the lower part of the sections the bands became thicker. Nicely 
visible from the thin section observations was the movement of material down the section in two, probably synchronous, phases. One of them was the movement of the silty fraction, which may later become a kind of block for the moving clay fraction. Different phases of the development of such accumulations were observed here.

The changing lithology from sand towards loess was visible, not only macroscopically and by the grain size distribution, but also by the change of the geochemical signal. Comparing the lower part of the section containing the illuvial bands with the horizons above the material, it became sandier down the section - with a nearly missing clay-fraction at the very base of the section. Compared with the quite homogenous soil horizons developed on the loess, the sandy horizons together with the illuvial bands showed a slightly increasing alkalinity, as well as increasing values of organic matter, surprisingly even higher than in the recent ploughed soil. On the other hand, the recent ploughed layer shows the presence of fertilizers: reflected in the increased values of $\mathrm{P}$. Other geochemical proxies are more variable, with moderately higher values in the part with illuvial bands compared to the horizons above, there mainly being an increase of $\mathrm{Mg}$ followed by $\mathrm{K}, \mathrm{Fe}, \mathrm{Al}$ and $\mathrm{Mn}$. Magnetic susceptibility enhancement does not follow these trends, and the highest values were detected in the recent ploughed horizon and at the bottom of the loess layer at a depth of $50 \mathrm{~cm}$.

\section{Discussion}

\subsection{Processes of formation of illuvial bands}

The reason the studied sites were included in this project is that they seem to be quite similar on first inspection and may reflect a common situation that archaeologists will face. However, in fact, the only similarities between them are that they are both located on a similar geological substrate (sand), were influenced by human occupation, and that illuvial band features developed there over time. By contrast, they differ by their geomorphological position, microclimatic region, background formation processes, and possibility of availabile underground water, as well as the time span of human influence and the illuvial features developed there. Is it possible, in spite of all these differences, to presume similar formation processes for their bands?

The presence or absence of primary "discontinuities", which may be (according to Bouabid et al., 1992), the reason for the bands origin, was excluded using the micromorphological approach in both localities. According to the shape of the silty features in the case of the Sowin locality, it seems that the leaching and transportation of clay material occurs commonly together with the leaching of the silt fraction, and probably also with the transportation of organic residues (see amounts of TOC - best visible for the Sowín site, Figure 4). At the same time, the redeposited silt fraction composes some kind of barrier (or grain size discontinuity), which stops the clay movement. This scenario was difficult to confirm for the Kly locality, because the infill of archaeological features is generally less sorted than the naturally-developed, geological background in the Sowin locality, but in both sites it is evident that the primary trigger for the bands origin is the increased precipitation. One other possibility for the band formation may be the presence of thawing permafrost (Siuta and Motowicka, 1965; Morozova, 1981; Manikowska, 1985; Kemp and McIntosh, 1989). This hypothesis may be linked to the bands located in the lower parts of Sowin sections, but this hypothesis is difficult to confirm. These bands are developed in web-like features and are more common, but we suggest, that it is more likely that time is the main factor. In spite of this, the role of thawing permafrost as one of the possible triggers cannot be excluded. The Kly locality is not calcareous, so the lower limit for the formation cannot be dependent on the presence of calcareous zones (Van Reeuwijk and de Villiers, 1985; Schaetzl, 1992), but more likely on the lower limit of the wetting front (Schaetzl, 1992). This factor may play a role in the case of the Sowín locality, where the horizons of loess have remained preserved up until today.

Questions concerning the formation processes, and, in particular, the direction in which the bands grow, may also be discussed from the point of view of the shape of these lamina. According to Van Reeuwijk and de Villiers (1985) and the (US) Soil Survey Staff (1999), the illuvial features grow upward, whereas Schaetzl (2001) and Ibrahim (2011) argue that the process may work by growing downward if there is some discontinuity connected with the wetting front. In the case of our study sites, the thickness and/or frequency of the illuvial bands mean they obviously grow upwards, which also confirms the original suggestion that these bands originated by way of water precipitation.

It seems that the development of illuvial bands, in the case of the Sowín locality, started before loess deposition and continued when the sandy sediments were again exposed to the surface. The aeolian origin (Tsigirintsev, 1968) of the substrate, in the case of Kly, is excluded, but very likely aeolian transport is confirmed for the Sowin locality. When the surface, composed of aeolian sand, was covered by loess, the leaching did not take place due to different reasons. One of these reasons is that it is the alkalinity of the loess substrate which stops the clay movement, and the second is the lack of precipitation during the glacial period. We do not have any proof of forest vegetation, but obviously the humic acids (recorded as TOC, Mg, and $\mathrm{K}$ - see Figure 4) were transported downwards together with the clay, so the surface was vegetated during the illuviation (Rejšek et al., 2017). The increased presence of humic acids, together with the elements connected with these accumulations, is obviously - in spite of the presence of Fe oxides - more diamagnetic than the surrounding substrate, corresponding as it does with the low enhancement of the magnetic signal (Figures 3,4). Continuous leaching during/or after loess deposition, in the case of the Sowín site, is recorded by the increased values of $\mathrm{Ca}$ (Figure 4). 


\subsection{Age of the illuvial bands and the state of their development}

As mentioned above, the age of the recorded bands is quite different - according to the stratigraphy of the sites. In the case of the Kly site, the age of the bands has to be post Neolithic and probably did not originate before to such an extent. This corresponds to the findings of Gayel and Khabarov (1969), Khabarov (1977), Torrent et al. (1980) and Aleksandrovsky (1983), who suggest that the bands in these types of soils would have formed during the Atlantic climatic optimum ca. 8400-5100 BP. Prusinkiewicz et al. (1998) suggest the age of these bands found within infillings of Neolithic features is a result of the Subboreal period (ca. 5100-2800 ${ }^{14} \mathrm{C} \mathrm{BP}$ ), which is more likely the case for the Kly site. The Sowin site displays much older formation processes for these bands. The presence of the loess horizon (Figur 4) and the appearance of well-developed bands below that horizon suggest their origin is glacial or, more likely, of interglacial age. Another proof of the glacial environment during or after the origin of the thick illuvial bands is the presence of frost cracks. On the other hand, bands postdating the Epigravettian and/or Magdalenian were also observed. All this together would correspond to the suggestions of Siuta and Motowicka (1965), Morozova (1981), Manikowska (1985) and Kemp and McIntosh (1989), who presume that these bands were formed at the end of the Pleistocene in the presence of permafrost. However, the detailed explanation of these processes is beyond the scope of this paper.

At the Kly site (Figure 2), there were detected wave-like bands with a number of discontinuities. The concentration of clay in these quite-thin and -light bands was quite low. These bands are dated most likely as post Neolithic, i.e., their age is relatively young, corresponding with the Subboreal period (Prusinkiewicz et al., 1998) or younger. Such types of bands correspond, according to the Soil Survey Staff, to the type of bands that develop nearer to the soil surface. The presence of wavy bands near the surface was also confirmed by Robinson and Rich (1960). However, contrary to this, the bands recorded micromorphologically at the Sowin site have a higher clay concentration, which seems to be even denser near the upper surface of the band, while the coarse clasts are concentrated in the lower part of the band. Such types of bands correspond with the so-called "lamellae in the middle zone" described by Van Reeuwijk and de Villiers (1985), and more recently by (US) Soil Survey Staff (1999). The much more developed type of features probably reflects the longer time period for their development, which also corresponds with the archaeological finds.

\subsection{Information value of illuvial bands for understanding the archaeological record}

The presence of a clay coating in an archaeological context may lead to interesting interpretations. Usually this is interpreted as being the result of two main factors. One of them is connected with the climate, namely with the higher precipitation and warmer conditions (Pelle et al., 2013), especially during the Neolithic. This finding would be well comparable with the Kly site, but we are not able to confirm whether the clay coating observed at Kly is connected with Neolithic deposition, or if it is a question of a much younger deposition. The lower part of the ditch infill probably originated very quickly, as confirmed in other localities (Lisá et al., 2015), so its age should be linked with the Neolithic. Furthermore, other authors (Catt, 1989; Cremaschi and Trombino, 1998; Scarciglia et al., 2009; Bernasconi, et al., 2010; Pelle et al., 2010) have documented clay coatings and placed their origin to the early-middle Holocene climatic optimum; so it is very likely that the coating observed at the Kly site is synsedimentary and/or postsedimentary right after the deposition of the material and influenced mainly by the climate. A similar study to Kly has been undertaken by Prusinkiewicz et al. (1998) at the Neolithic site of Kujawy, Poland. This researcher observed that the illuvial bands were probably formed in the period of the Subboreal, probably quite soon after the pits were infilled $\left(4700-4800{ }^{14} \mathrm{C} \mathrm{BP}\right)$.

The second main factor related to the origin of illuvial bands may be connected with agriculture, or simply with the presence of people who influenced the vegetation, as well as the soil record, by their waste material. There are a number of references from northern Europe discussing the connection of Placid horizons (iron, iron-manganese, or iron-amorphous organic-matter panning) with agricultural maintenance (Macphail, 1990; Reynolds and Catt, 1987). It is difficult to imagine the agricultural impact on the development of the illuvial bands inside the infill of a deep ditch in the case of the Kly site, but it should be at least kept in mind for the upper part of the sedimentary cover at the Sowín site. On the other hand, the effect of waste deposition, which is able to change the $\mathrm{pH}$ and therefore inhibit the clay movement, would be a possibility. The formation of a clay concentration according to such a scenario was suggested by Novák et al. (2012) in the case of the Early Slavic site of Roztoky without the link to a climatic influence; there were waste dump depressions still visible with the clay concentrations below. On the other hand, such accumulations were not detected at either the Kly or Sowin sites. The possibility of a history of alteration from argillic brown earth soils to podzols is intriguing - and would be very interesting to explore further, especially in relation to prehistoric land-use practices. This type of soil profile change is familiar to many areas of north-west Europe, and has been frequently related, at least in theory, to ancient landuse practices.

\section{Conclusion}

The combination of micromorphology and pedogeochemistry makes a suitable tool for better understanding formation processes. Although both of the sites presented here have different ages, formation histories, and geographical (as well as geomorphological) conditions, they display a number of illuvial bands. Whereas these features at the Kly site probably originated during the Subboreal, due to the increased humidity connected with the presence of a disturbed ditch- 
infill background, the Sowin site displayed at least two phases for the origin of these bands. One of them is pre-dated by glacial conditions, and the second one is a late glacial or Holocene origin. At both sites, the influence of humans seems to be unlikely. The origin of the illuvial band features was due to the precipitated water that brought Fe hydroxides and sesquioxides down, together with organic matter, $\mathrm{K}, \mathrm{Mg}$ and $\mathrm{Mn}$, to the section. It is more likely that the illuviated material was not only clay but also a silty fraction. The presence of bands, their thickness and frequency, is not dependent on primary grain size discontinuities, but these are more likely to originate during the illuviation. The result of illuviation is time- and precipitation-rate dependent. The presence of illuvial bands within an archaeological site, therefore, should be precisely placed into the geochronological context of the site, because the origin of these features may be linked to the climatic conditions of a different age. The presence of illuvial bands in the infill of Neolithic features will be most likely linked to the infill disturbance and increased Subboreal humidity, whereas the presence of such features outside of the archaeological objects may have many more scenarios for their origin.

\section{Acknowledgements}

This study was supported by the Grant Agency of the Czech Republic, project Protoeneolithic enclosures in Bohemia, interpretation of their purpose and social meaning (Grant No. 15-02453S), by internal programme of the Institute of Geology CAS in Prague RVO 67985831, and by the project funded by the National Centre of Science (UMO-2014/13/B/ HS3/04906), Strategies of occupation of the Late Palaeolithic hunters and gatherers in Polish uplands: case study of site complex from Sowin, Opole voivodship.

\section{References}

ALEKSANDROVSKY, A.L., 1983. Evolution of Soils of the Eastern European Lowland during the Holocene. Moskva: Nauka.

BERNASCONI, M.P., CHIOCCI, F.L., CRITELLI, S., LA RUSSA, M.F., MAROZZO, S., MARTORELLI, E., NATALI, E., PELLE, T. ROBUSTELli, G., RUSSO ERMOLLI, E., SCARCIGLIA, F., TINÉ, V., 2010. Multi-proxy reconstruction of Late Pleistocene to Holocene paleoenvironmental changes in SW Calabria (southern Italy) from marine and continental records. Il Quaternario e Italian Journal of Quaternary Sciences, 23(2), 249e256.

BOUABID, R., NATER, E.A., BARAK, P., 1992. Measurement of pore size distribution in a lamellar Bt horizon using epifluorescence microscopy and image analysis. Geoderma, 53, 309-328.

CATT, J.A., 1989. Relict properties in soils of the central and north-west European temperate region. Catena Supplement, 16, $41 \mathrm{e} 58$.

CREMASCHI, M., TROMBINO, L., 1998. The palaeoclimatic significance of paleosols in Southern Fezzan (Libyan Sahara): morphological and micromorphological aspects. Catena, 34, 131e156.

GAVEL, A.G., KHABAROV, A.V., 1969. On specificity of soil-forming processes on sands of Khernovsky Forests. Pokhvovedenie, 11, 17-31.

GERASIMOVA, M.I., KHITROV, N.B., 2012. Comparison of the Results of Soil Profile's Diagnostics Performed in Three Classification Systems. Eurasian Soil Science, 45(12), 1087-1094.
GOJDA, M., DRESLEROVÁ, D., FOSTER, P., KŘIVÁNEK, R., KUNA, M., VENCL, S., ZÁPOTOCKÝ, M., 2002. Velké pravěké ohrazení v Klech (okr. Mělník). Využití nedestruktivních metod výzkumu kpoznání nového typu areálu, Archeologické rozhledy, 54, 371-430.

GRANT, R., LAUBEL, A., KRONVANG, B., ANDERSEN, H.E., SVENDSEN, L.M., FUGLSANG, A., 1996. Loss dissolved and particulate phosphorus from arable catchments by subsurface drainage. Water Research, 30, 2633-2642.

IBRAHIM, A.M.A., 2011. Argillic horizons and clay-sized particles - an alternative interpretation of their dynamics in sola development and across catenas. Unpublished thesis (PhD), Iowa State University.

KEMP, R.A., MCINTOSH, P.D., 1989. Genesis of a texturally banded soil in Southland, New Zealand. Geoderma, 45, 65-81.

KHABAROV, A.V., 1977. Soil-Forming Processes on Sands in the Southwest of the Russian Lowland. Moskva: Nauka.

KOSTER, E.A., 2009. The "European Aeolian Sand Belt": Geoconservation of Drift Sand Landscapes. Geoheritage, 1, 93-110.

KRIŠTŮF, P., TUREK J., et al., 2019. Arény předků: posvátno a rituály na počátku eneolitu. Plzeň: Vydavatelství ZČU.

KÜHN, P., AGUILAR, J., MIEDEMA, R., 2011. Textural pedofeatures and related horizons. In: G. Stoops, V. Marcelino, V. Mees, eds. Interpretation of micromorphological features of Soils and Regoliths. Amsterdam: Elsevier, pp. 217-250.

LISÁ, L., KOMORÓCZY, B., VLACH, M., VÁLEK, D., BAJER, A., KOVÁRNÍK, J., RAJTÁR, J., HÜSSEN, C.M, ŠUMBEROVÁ, R., 2015. How were the ditches filled? Sedimentological and micromorphological classification of formation processes within graben-like archaeological objects. Quaternary International, 370(3), 66-76.

LÜNING, J., 1968. Die Michelsberger Kultur. Ihre Funde in zeitlicher und räumlicher Gliederung. $B R G K, 48,1-350$.

MACPHAIL, R.I., COURTY, M.A., GEBHARDT, A., 1990. Soil micromorphological evidence of early agriculture in north-west Europe. World Archaeology, 22, 53-69.

MANIKOWSKA, B., 1985. On the fossil soils, stratigraphy and lithology of dunes in Central Poland. Acta Geographica Lodziensia, 52, 1-137.

MIEDEMA, R., 1987. Soil Formation, Microstructure and Physical Behaviour of Late Weichselian and Holocene Rhine Deposits in the Netherlands. Unpublished thesis (PhD), Agricultural University, Wageningen, The Netherlands.

MOROZOVA, T.D., 1981. The Development of Soil Mantle of Europe in Late Pleistocene. Moskva: Nauka.

NOVÁK, J., LISÁ, L., POKORNÝ, P., KUNA, M., 2012. Charcoal analyses as an environmental tool for the study of Early Medieval sunken houses infills in Roztoky near Prague, Czech Republic. Journal of Archaeological Science, 39. 808-817.

PELle, T., SCARCIGLIA, F., ALlEVATO, E., DIPASQUALE, G., LA RUSSA, M.F., MARINO, D., NATALI, E., ROBUSTELli, G., TINÉ, V., 2013. Reconstruction of Holocene environmental changes in two archaeological sites of Calabria (Southern Italy) using an integrated pedological and anthracological approach. Quaternary International, 288, 206-214.

PElle, T., SCARCiglia, F., ROBUStelli, G., AlleVATO, E., DI PASQUALE, G., MITRO, R., MARINO, D., 2010. Multidisciplinary study of Holocene soils in the archaeological sites of Cecita Lake (Sila Massif, Calabria, Italy): paleoenvironmental reconstruction.In: Atti del convegno "Scienze Naturali e Archeologia e Il paesaggio antico: interazione uomo/ambiente ed eventi catastrofici", Napoli, 14e16 Octobre 2010. Roma: Arcane, 183-187.

PRUSINKIEWICZ, Z., BEDNAREK, R., KOSKO, A., SZMYT, M., 1998. Paleopedological studies of the age and properties of illuvial bands at an archaeological site. Quaternary International, 51/52, 195-201.

PRZBYLSKI, B., BADURA, J., 2001. Szczegółowa mapa geologiczna Polski w skali 1: 50 000, arkusz Niemodlin /872/, Warszawa.

REJŠEK, K., TUREK J., VRÁNOVÁ, V., HADACZ, R., LISÁ, L., 2017. Is it possible to determine formation processes of organic deposits through polysaccharides? Pilot study from the prehistoric site in Brandýs nad Labem, Czech Republic. The Holocene, 27(9), 1-8.

REYNOLDS, K.S., CATT, J.A., 1987. Soils and vegetation history of abandoned enclosures in the New Forest, Hampshire, England. Journal of Archaeological Science, 14, 507-527.

ROBINSON, G.H., RICH, C.J., 1960. Characteristics of the multiple 
yellowish-red bands common to certain soils in the southeastern United States. Soil Science Society of America Proceedings, 24, 226-230.

SCARCIGLIA, F., ROBUSTELLI, G., TINÉ, V., LA RUSSA, M.F., ABATE, M., PEZZINO, A., 2009. The role of human impacts and Holocene climate change in the Santuario della Madonna Cave (Calabria). In: V. Amato, N. Marriner, C. Morhange, P. Romano, E. Russo Ermolli, eds. Geoarcheology in Italy. Méditerranée. 112, 137-143.

SCHAETZL, R.J., 1992. Texture, mineralogy and lamellae development in sandy soils in Michigan. Soil Science Society of.America Journal, 56, $1538-1545$.

SCHAETZL, R.J., 2001. Morphologic evidence of lamellae forming directly from thin, clayey bedding planes in a dune. Geoderma, 99, 51-63.

SIUTA, J., MOTOWICKA, T., 1965. Genesis of horizontal iron layers in sandy soils. Pamictnik Pulawski, 18, 111-128.

Soil Survey Staff, 1999. Soil Taxonomy. $2^{\text {nd }}$ ed., Washington, DC.: USDA Agric. United States Government Printing Office.

STEFANOVITS, P. 1971. Brown Forest Soils of Hungary. Budapest: Akademiai Kiadó.

TORRENT, J., NETTLETON, W.D. and BORST, G., 1980. Clay illuviation and lamella formation in Psammentic Haploxeralf in southern California. Soil Science Society of America Journal, 44, 363-369.
TSIGIRINTSEV, I.P., 1968. On nature zebra like layers in sandy deposits. Voronez: Voronez University.

UGGLA, H., UGGLA, Z. 1979. Forest Soil Science. Warszawa: PWRiL.

VAN REEIWIJK, L.P., de VILLIERS, J.M., 1985. The origin of textural lamellae in Quaternary coastal sands of Natal. South African Journal of Plant and Soil, 2, 38-44.

WIŚNIEWSKI, A., POŁTOWICZ-BOBAK, M., BOBAK, D., JARY, Z., MOSKA, P., 2017. The Epigravettian and the Magdalenian in Poland: new chronological data and old problem. Geochronometria, 44, 16-29.

WIŚNIEWSKI, A., BADURA, J., FURMANEK M., HNAT, M., PRZYBYLSKI, B., RAPIŃSKI, A., 2009. Prace wykopaliskowe na stanowisku 9 w Sowinie, województwo opolskie. In: Badania Archeologiczne na Górnym Śląsu i Ziemiach Pogranicznych w latach 2007-2008. 15-24.

WIŚNIEWSKI, A., FURMANEK, M., BOROWSKI, M., KĄDZIOŁKA, K., RAPIŃSKI, A., WINNICKA, K., 2012. Lithic raw material and Late Palaeolithic strategies of mobility: a case study from Sowin 7, SW Poland. Anthropologie, 50(4), 391-409. 